\title{
TRACKING SYLVIA TOWNSEND WARNER'S RED FOOTSTEPS IN LOLLY WILLOWES
}

\author{
June E. Dunn
}

In a 1925 letter to David Garnett, Sylvia Townsend Warner bemoans the response her novel Lolly Willowes has elicited from readers: 'Other people who have seen Lolly have told me that it was charming, that it was distinguished, and my mother said that it was almost as good as Galsworthy. And my heart sank lower and lower (1982 p.8). Warner's reaction to the reception her novel received initially seems rather surprising - what novelist would not want approval for her incipient career as a writer, and the approval, no less, of her own mother who likens the work to that of an esteemed and highly conventional writer? After all, 'charming' seems a fitting term to apply to a novel whose titular character forsakes a predictable spinsterhood in her brother's home in London for the uncertain and fantastic life as a witch in the Chilterns. Yet one gathers from Warner's reaction that her authorial intention for Lolly Willowes was less about charming her readers and more about provoking them. 
As critics have indicated, Warner invests her 1926 novel with feminist commentary that presages much of what Woolf argues in A Room of One's Own (1928)', and Warner may not have expected that Laura's unconventional lifestyle and her exposition to the Devil about why women become witches to have been so enthusiastically received by the general reading public. However, Warner's novel 'embodies a far more subtle politics' (Shin, 2009 p.710) in addition to the feminism it advocates. The sociopolitical consciousness that Laura develops throughout the novel mirrors Warner's own with regard to her emerging communism. While writing Lolly Willowes Warner was concurrently envisioning the central characters of Summer Will Show (1936), for in a note dictated by Warner to Valentine Ackland about the genesis of the latter, Warner indicates that she had first conceived of Sophia Willoughby and Minna Lemeul in the early 1920s, and it was not until 1932 after she and Ackland went to Paris that she 'wanted to write a novel about 1848', at which point 'Sophie and Minna started up and rushed into it' (Warner, 1986, p. x). Furthermore, the walks that Laura takes about London, sites endowed with particular socioeconomic and Jewish significance, portend both Laura's class consciousness-raising in Lolly Willowes and the Anglo-Jewish collaboration that Warner develops more fully in Summer Will Show. Ultimately, the aforementioned references to Warner's nascent communism and her formation of the central characters of her pro-communist novel Summer Will Show while writing Lolly Willowes, combined with her decision to have Laura move to Buckinghamshire and become immersed in a mixed-class coven whose Devil eschews the trappings of social privilege, indicate that Lolly Willowes is a decidedly more radical text than previously acknowledged. Nor is the choice of Buckinghamshire accidental, for this English county has been long associated with Robin Hood who in turn has been allied with the Devil in his incarnation as Robin Goodfellow, and as Glen Cavaliero has pointed out, it also has links with the radicals John Milton and William Penn. 
As Jennifer Poulos Nesbitt demonstrates in 'Footsteps of Red Ink: Body and Landscape in Lolly Willowes,' Warner 'makes the landscape a material presence, an agent in Laura's struggle for place' (2003, p.450), and the spaces that she inhabits or moves through in the novel signify her navigation through her internal landscape as it resonates with sites associated with British imperialism and patriarchal dominance in general. These sites also point to the history of nonconformist thought in England and its concomitant association with seditiousness. For instance, as Laura becomes more unhappy living with her family in London, her mind starts 'groping after something that eluded her experience' as a privileged woman, "a something that was shadowy and menacing, and yet in some way congenial. . .,' and to find that something she would 'go off to explore the City churches, or to lose herself in the riverside quarters east of the Pool $^{2}$,' or in thinking of Defoe's Journal, 'fancy herself back in the seventeenth century, when, so it seemed to her, there were still darknesses in men's minds, almost pouncing 'on the clue to her disquiet' by the 'jostling tombstones at Bunhill Fields' (all p.43). Jane Marcus posits that Laura's attraction to such places is that she 'wants the magic and mystery and finds the alien places in London where she can feel natural magic at work' (1984, p.152), and while this is one aspect of the draw for Laura, there is an underlying sociopolitical pull for her as well.

Bunfield Hills Cemetery is notable for being 'for more than two centuries the chief burial-place of Nonconformists,' containing the remains of such prominent individuals as John Bunyan, Daniel Defoe, Susannah Wesley, 'mother of John and Charles Wesley,' Henry, Richard and William Cromwell, 'descendants of the Protector,' and Religious Society of Friends' founder George Fox (Ward, Lock \& Co. p.221). Laura, who as a child had 'Oliver Cromwell the toad' as a companion (1986, p.10), was 'bored' by the established church that Henry and Caroline attended and was 'darkly, adventurously drawn to see what services were like amongst Roman Catholics, amongst Huguenots, amongst 
Unitarians and Swedenborgians, feeling about this rather as she felt about the East End' (p.30). The nonconformist quality of Laura, present in childhood and suppressed upon moving to her brother's home in London, reemerges as she ventures like a flâneuse across the city, from the west of Apsley Terrace, to the north of Hampstead (where Sybil and Titus reside) and Bunhill Fields, to the east of the Pool, and the allied 'darkness' both of thought and site for her is centred on the East End.

Laura's attraction to a section of the city far-removed from her life of upper-middle-class convention is reflective of Warner's own sociopolitical development, albeit at a much earlier time in her life than her titular character's. Warner's consciousness regarding class politics most likely emerged when she joined the Women's Relief Munition Workers' Organisation in 1915 and had the opportunity to work alongside male and female factory workers (Wachman, 2001, p.73) ${ }^{3}$. The political consciousness she gained from that initial experience undoubtedly transferred into her writing, for as Wachman aptly notes, Warner's 'insights into the class system are central to all her work' $(2001$, p. 74$)$. In Lolly Willowes, in addition to the centrality of the class system to the story, Warner shows the necessity in considering the importance of Jews to that understanding.

Laura's attraction to the East End, besides it being imbued with nonconformist, anti-establishment sensibilities within a working-class milieu, is its Jewish identity and concomitant link with communism. While the East End has long been associated with the proletariat, from dock to produce to sweatshop workers, Jews have also had a conspicuous presence in this section of the city, particularly with Russian-Jews in the latter half of the nineteenth century (Polly Beals). According to a thinly veiled anti-Semitic entry in a period guidebook, London 1914: A Pictorial and Descriptive Guide to London and Its Environs, the Aldgate area was notable for its Jewish population: 
Hereabouts, as a glance at shop signs and passing faces betrays, is the Jewish quarter of the Metropolis. Turning to the left, we pass close to St. James's Palace, in which is the Great Synagogue [emphasis original to source], the Hebrew Cathedral of London, standing on a site which has been similarly occupied ever since the re-admission of the Jews to England. ${ }^{4}$ There are other synagogues close at hand in Bevis Marks, Fenchurch Street, etc. (p.234)

In Lolly Willowes, as the autumn progresses and Laura has found no cathartic release to her ennui as she pursues her walks across the city, she tells herself that 'if she still went on expeditions to Rotherhihe or the Jews' BuryingGround, she went in search for no more than a little diversion' (p.43). And then, in the winter of 1921, on an errand to Earls Court Road for Caroline, Laura returned home by way of a "circuitous route, including the two foxes who guard the forsaken approach in Holland Park and the lane beside the Bayswater Synagogue. ${ }^{5}$ It was in Moscow Road that she began to be extravagant' (p.46).

The conflation of working-class and Jewish markers by Warner, particularly when all roads Laura has been walking lead to Moscow (Road) to the shop in which she has her epiphany of moving to the Chilterns, strongly suggest the connections between class, consciousnessraising, and communism. Although Warner did not officially join the Communist Party of Great Britain until 1935 (Warner, 1982 p. xiv), the sociopolitical conditions in England at the time she was writing Lolly Willowes were steeped in social unrest and class conflict, in large part due to the high post-war unemployment rate and shifting cultural values. In 1920 the Communist Party of Great Britain was established, and though membership was small at the onset, the Party had its sympathisers: "They included the dockers who in the spring of 1920 refused to load arms onto ships bound for Poland, where they were intended to be used against the Red Army ${ }^{6,}$ and 
'also included the miners who struck in October that same year' (Lucas, 1999, p. 44). By the winter of 1921 (when in the novel Laura decides to leave London for Great Mop), Great Britain had experienced a 'year of strikes,' and by 1926, when the novel was published, the "first Labour government had been elected' (Lucas, 1999, p.104). Furthermore, between 1917 and 1929, "Jews were found in disproportionately high numbers in a wide variety of political and cultural fields', and Jewish 'support for revolutionary causes remained correspondingly high during this period' (Horowitz, 1986, p.17).

While Summer Will Show most directly posits an Anglo-Jewish connection with regard to communist ideology in that an aristocratic English woman named Sophia Willoughby becomes lovers with her husband's former mistress, Minna Lemeul, a Jewish revolutionary, Warner had tentatively created both characters at the time she was writing Lolly Willowes ${ }^{7}$. In William Maxwell's introduction to Four in Hand, he cites a note dictated in the mid-1960s by Warner to Valentine Ackland regarding her creation of Summer Will Show. It states that 'in 1920 or '21' Warner told Robert Firebrace that she had invented a 'Victorian young lady of means' with a 'secret passion for pugilism', who 'attended prize-fights dressed as a man and kept a punching-ball under lock and key in her dressing-room', who was 'smooth, fair hair, tall, reserved, very ladylike' and named Sophia Willoughby. Warner further notes that 'a year or so later and equally out of the blue [she] saw Minna telling about a pogrom in a Paris drawing-room' (Warner, 1986, p. x). Although Lolly Willowes is not as overtly political in its discussion of communism and Anglo-Jewish connections as Stmmer Will Show, the sociopolitical context of the times in which Warner was writing Lolly Willowes, her contemporaneous imaginings for a future novel of two characters from diverse class and ethnic backgrounds (one of whom is Jewish and survives a pogrom), and the sitespecific consciousness-raising pilgrimages that Laura makes in Lolly Willowes strongly indicate that she was 
intentional in correlating Laura's emerging identity with a necessary sociopolitical awareness. The egalitarian, communal aspects of nonconformist ideology espoused by such English figures as those buried in Bunhill Fields and the intemational communist principles promulgated by Jewish notables such as Marx and Trotsky are analogous (if imperfect) in many ways, yet provide a historic stile upon which Laura may embark towards her new life." The map she marks with 'little bleeding footsteps of red ink' of her trekking in Great Mop (1986, p. 61) may indicate Laura's 'infusion of herself, her spirit and her very life, back into her beloved earth and nature' (Knoll, 1993, p.354) or 'distantly allude to her rebellion as a woman by evoking menstrual flow' (Nesbitt, 2003, p. 460$)^{9}$, yet these red footsteps may also reflect Warner's traversing upon her path to communism through her character's steps.

While Warner's choice of the Chilterns as Laura's destination out of the patriarchal metropolis and into the atavistic woods is, as Knoll suggests, evidence of 'the tremendous split between the male and female ethics in Townsend Warner' (p.355), Laura's move to an area of England deeply associated with folklore surrounding the social bandit Robin Hood further augments the revolutionary subtext of both the novel and Laura's emerging identity. After Laura is given sprays of beech leaves from the shop owner on Moscow Road who acquired them on his visits to his sister in Buckinghamshire, 'Laura knew all that she wanted to know. . . Her course lay clear before her,' and takes her beech leaves as if she were 'marching on Dunsinane' to a bookseller's (1986, p.48). There she purchases a guidebook of the Chilterns that provided detailed maps and included minutia of the area such as its geology and 'Flora and Fauna, Watersheds, Ecclesiastical Foundations and Local Government,' the population of Chiltern's towns, and descriptive notes of local places of interest (p. 48), much like Muirhead's Blue Guide to England. In the 1924 edition of the Blue Guide, under chapter 48 'From London to Nottingham and Sheffield," Muirhead's 
depiction of 'the beech-clad CHILTERN HILLS, a picturesque group of chalk downs, with a maximum height of about $900 \mathrm{ft}$.' includes a historical note:

The only way in which a member of Parliament may voluntarily vacate his seat is by accepting an office of profit under the Crown, and the Stewardship of the Chiltern Hundreds (Stoke, Desborough, and Burnham) is the office for which application is usually made with that end. The nominal duty of the Steward is to protect the inhabitants of the hundreds from bandits (who once lurked in the thick beech-forests), and his nominal salary is $20 /{ }^{10}$ (Muirhead, 1924 p.384)

Laura's reference to Macbeth in light of her decision to leave London for the Chilterns, combined with the historical/political information of Muirhead's guide conflated with the Robin Hood/Sheriff of Nottingham folklore, underscores her identification with the dispossessed. In both Macbeth and the Robin Hood tales, tyrannical interlopers usurp the thrones of the true kings and the rightful heirs and their defenders take to the woods to mount their offensives to re-establish societal order. For Laura, her family is initially most closely associated with the tyranny she must escape. After regaining control of her legacy that was mismanaged by Henry and leaving Apsley Terrace to live in Great Mop, Laura comes to the conclusion after a few months away from London that

She was changed, and knew it. She was humbler, and more simple. She ceased to triumph mentally over her tyrants, and rallied herself no longer with the consciousness that she had outraged them by coming to live at Great Mop. The amusement she had drawn from their 
disapproval was a slavish remnant, a derisive dance on the north bank of the Ohio. (p.81)

Laura recognizes that her alignment of her family with 'tyrants' and herself with an escaped slave was indicative of an oppression more endemic than the microcosm of the family, and that her reactive response to their outrage and disapproval was impotent in that it did not effect constructive change. To forgive her family for its mistreatment of her was not possible for two reasons: she did not have a forgiving nature and the offence of her family's tyranny over her originated in society. She notes that

If she were to start forgiving she must needs forgive Society, the Law, the History of Europe, the Old Testament, great-great-aunt Salome and her prayer-book, the Bank of England, Prostitution, the Architect of Apsley Terrace, and a dozen other useful props of civilization. (pp.81-82)

Instead of forgiving, Laura decides to forget her family and civilization's props. Knoll contends that Laura's stance on 'forgetting rather than forgiving' to be a mark of self-assertiveness on her part in that 'forgiveness connotes a certain power or status the forgiver has over the offender, and Laura rejects even that power' (1993, p.355). But Warner's sociopolitical consciousness will not allow Laura to avoid the inevitable confrontation she must have with herself regarding her family's complicity with society, and her own with both. Forgiving or forgetting tyrants, the law, history, religion, capitalism, prostitution, and the like will not result in constructive social or personal change; without modifying society there will always be more Macbeths, King Johns, and Henrys to fill the void left by former tyrants. As Gillian Beer notes with regard to Warner's character development in her novels, 'Warner refuses to let the personal dominate the political entirely $(1999$, p.83). One 
must meet history and one's family head-on to effect revolutionary change, and Warner ensures that for Laura with her nephew Titus's decision to join her Great Mop, and with Robin Hood in the form of the Devil.

Although anthropologist and occultist Margaret A. Murray liked Warner's witch but was 'doubtful about [her] devil,' the two women did meet for lunch and discussed things 'that would make the hairs on [one's] head stand bolt upright' (Warner 1982, p.9). According to Murray, first in The Witch-Cult in Western Europe (1921) and then with more specificity in The God of the Witches (1931), that there are a number of cultural examples in which the devil is referred to as 'Robin.' Christianity transposed the figure of the Horned God of the 'Old Religion,' the god of the witches, into that of what we commonly perceive as the Devil, and that the generic name of 'Robin' or 'Robin Goodfellow' has often been applied to this figure ${ }^{11}$ (Murray, 1931, pp.40-41). She further notes that there is a strong association between 'Robin Goodfellow and Robin Hood,' and that 'in Scotland as well as England Robin Hood was well known, and he belonged essentially to the people, not the nobles' (1931, p.41). Warner's Devil in Lolly Willowes may not have been called 'Robin,' but the concept of Robin Hood as both a motivating force for socioeconomic parity and cross-class collaboration is very much indicative of her Devil in the novel, and indicative of the politics Warner will more fully espouse in her later works, such as Summer Will Show, and in her shorter fiction.

The 'footsteps in red ink' that Laura began taking in London prior to her move to the Chilterns, from the nonconformists' burial grounds, to Jewish-identified parts of the city, to Moscow Road have led her to the village of Great Mop, a name associated with a gathering place for the proletariat in search of work who would carry tools associated with their particular posts, such as mops, to the gatherings ${ }^{12}$. For Laura, her move to the Chilterns signals her emerging identification with the oppressed and disenfranchised as a whole, and the implications that gender holds in particular. This impending collaboration 
is suggested just prior to Laura's announcement of moving from Apsley Terrace. While she is resting in her room after her travels and epiphany at the shop on Moscow Road, a servant enters the room with fresh hot water. Warner describes the woman, Dunlop, as "a perfectly trained servant' who, before leaving the room, 'took a deep breath, stooped down, and picked up a beech leaf' (p.49). This scene is significant in that the focus is not on Laura in her room (who seems unaware of Dunlop's presence) but rather on Dunlop and her actions. What draws Dunlop's attention is not the opulence of flowers in the room but the beech leaf on the floor, one of the leaves that provided the impetus for Laura's epiphany. Despite Dunlop's being the perfect servant in picking up something that is where it ought not be, this action more so represents a figurative interlude that Warner conducts in order to draw the reader's attention to Laura's impending transition. There will no longer be extravagant flowers or servants for Laura at Great Mop; instead, just like beech leaves and indigenous flowers, she will live among individuals sharing an in-kind calling, one that does not privilege one individual over another.

The members of the Great Mop coven range in socioeconomic spectrum such as the Misses Larpent, who are of old established family, Mr. Gurdon, the rector's clerk and gardener, Mrs. Leak with whom Laura lodged, and Emily, the village 'slattern' (p.104). By day the villagers conventionally proceed with their lives according to their social status; by night, however, the coven does not adhere as assiduously to class dictates at its Sabbaths. For instance, when Mrs. Leak brings Laura to her first Sabbath and they encounter Mr. Gurdon in his self-anointed position as gatekeeper, Mrs. Leak contemptuously tells Laura, "He thinks he can boss us here, just as he does in the village' (p.102). Yet shortly after that statement, Mrs. Leak

coughed in a respectful way, and dropped a deep curtsey. Before them stood and old lady, carrying herself like a queen, and 
wearing a mackintosh that would have disgraced a tinker's drab. She acknowledged Mrs. Leak's curtsey with an inclination of the head, and turned to Laura. (p.102)

Just as in any movement that challenges the hegemony (be it communist revolution or witch-crafting), there are some members who may be reluctant to entirely forgo their social standing, especially when that ranking is closely competitive. Mrs. Leak and Mr. Gurdon are as close in social status as Laura is to Miss Larpent, while Mrs. Leak is much farther removed from Miss Larpent and is thus deferential to her. Warner further parodies class convention by indicating that Miss Larpent both carries 'herself like a queen' and dresses in a way that would disgrace a tinker's unkempt wife, embodying the most possessed and dispossessed women in British society simultaneously. Despite these superficial needs to hang on to social protocol, all members of the coven dance and perform the Devil's work as equals, even if at break of day they return to their prescribed societal roles.

Unlike his followers, the Devil in Lolly Willowes is uninterested in displaying his lordly status and only appears to Laura in the form of a common man, much like the aristocratic Robin Hood among his merry men, or Robin Goodfellow who, "when inducing a possible convert to join the ranks of witch-society, . . . came in his own person, usually dressed plainly in the costume of the period ... indistinguishable from any other man of his own rank or age' (Murray, 1921, p.31). The Devil first appears as a gamekeeper to Laura and assures her that if she ever needs his assistance that she "will always find [him] in the wood' (Warner, 1986, p.110), his physical appearance and overall demeanour inspiring her to trust him. This image of the Devil as a man of (and with) the people resonates with communist ideals for a leader, especially with regard to this figure restructuring society more equitably. The Devil is thus akin with the figure of the social bandit as posited by Eric Hobsbawm in his 
formulation of the 'Robin Hood Principle'. According to this principle, the social bandit is 'a reality that motivates certain forms of political resistance to oppressive regimes within peasant societies' (Seal, 2009, p.67), and at the "core of the facts and fictions surrounding outlaw heroes remains the belief that he, or very occasionally she, robs the rich to give to the poor' (Seal, 2009, p.69). The Judeo-Christian God may be the oppressive regime that the Devil rebels against, but for the Devil's earthly followers like Laura, the tyrants of the home are the ones with whom they first need to contend before embarking on a larger course for far-reaching social change. In Titus, Warner creates a figure that embodies both the oppression of the home and the world for Laura, and a force that will require the Devil's intercession on Laura's behalf.

The journey from the shop on Moscow Road to Great Mop for Laura coalesces quite literally with Russian history in Titus's visit to the village, and signals the revolutionary forces at work in both greater society and in Laura's more immediate one. While Warner references years, months, and seasons throughout the novel, she is very specific about one date only in the text: 'On July $17^{\text {th }}$ [Laura] was disturbed by a breath from the world' (p.82). This is the date that Titus visits Laura at Great Mop and from that visit decides that he would live there as well, against her unspoken demands to the contrary. To a reader in 1926, this date would carry particular significance in that it is also the day the Russian royal family was slaughtered. 'The world' that disturbs Laura's sense of well-being is the same world that Warner discusses in her autobiographical story "The Golden Rose' from Scenes of Childhood. This story recalls a time 'when there was a Tzar in Russia' and when Warner's mother would have occasional visits by Miss Viner, a woman so travelled, knowledgeable about Eastern European politics, fluent in Balkan languages, and acquainted with so many diplomats that her mother suspected her of being a British secret agent' (Warner, 1981, p. 96). 
Miss Viner's visits, always intriguing to both Warner and her mother, ended in 1910 after her return from a traumatic excursion to a Russia plagued by 'police spies, and typhus, and censorship, and terrorism, and corruption' (p.99). When Warner's mother inquires about the Tzar 'and Tzarina, poor thing,' and 'all those Grand Dukes and Grand Duchesses,' Miss Viner replies, 'Miserable puppets!' (p.99). It was not until shortly after World War I that Warner encountered Miss Viner again in a teashop, overhearing her tell another woman that 'Of course, one of the Grand Duchesses is at this moment in Chicago[,] . . . But she had completely lost her memory' (p.100). The woman responds: 'You can't really wonder at that, considering what she's been through' (p.100). Wamer's vignette not only indicates that people in England were discussing the Russian Revolution and the fate of the Tzar and his family in the aftermath of the Great War, but that Warner thought this event significant enough to include as an artefact from her childhood that informed her consciousness as a young woman and as a writer ${ }^{13}$, for, as Kristianne Kalata notes, all Warner's stories in Scenes of Childhood serve 'to recreate and resituate her early life experience in a larger sociopolitical context' (2005, p.319). By conflating Titus's unanticipated (and undesired) visit to Great Mop with a date that would have held such immediate resonance with her contemporary readers, Warner is intent on having readers connect Laura's distress and need to be rid of familial oppression with the proletariat's need to be rid of its oppressors in Russia.

Just as Laura envisions herself as a rebel fighting against an unspecified oppression prior to her move to Great Mop, then identifies her family as that tyrannical force shortly after her move, Titus's visit to Great Mop and his subsequent decision to move there as well incites Laura's rage and provokes her 'rebellion against Titus and what he represents, the power to repress her real self into docile aunthood' (Marcus, 1984, 155). While Laura is not the same sort of Victorian lady-cum-communist revolutionary like the character Sophia in Stummer Will 
Show who kills her younger male relation in retaliation for killing her lover Minna, Laura nonetheless harbours harsh thoughts towards her own nephew that are actualized when she joins forces with the Devil. With the Devil's intervention, Titus's milk curdles (p.96); he gashes his thumb on tinned milk (p.113); he is besieged by flies (p.114); he is kept awake by a mouse gnawing on the leg of his bedstead (p. 115); he becomes anxious on his walks (p.115); and finally, he is attacked by wasps (p.117). Granted, the violence Titus experiences is understated compared to a tzar and his family being brutally killed in retaliation for his repressive regime, yet it is a violence that could easily be accepted by Warner's readers, many of whom may have had Tituses of their own at home with whom they needed to contend. Laura's alliance with the Devil, resulting in Titus's misfortune and departure from Great Mop, is something that she does not regret doing, for "Custom, public opinion, law, church, and state-all would have shaken their massive heads against her plea, and sent her back to bondage' (p.119). When Warner correlates familial tyranny and state-sanctioned tyranny, and an aunt's insurrection with a runaway slave or communist revolution, one may view the manoeuvre as an overreaching trajectory on her part, but the underlying power-structure in these cases remains the same. Titus's decision to move to Great Mop is thus reflective of 'an incipient paternal dictator of the kind Virginia Woolf describes in Three Guineas and a minor imperialist' (Nesbit, 2003, p.462), and the Plagues of Great Mop that are visited upon him only further underscore the relationship between hegemonic domination and slavery, particularly as it relates to women, Blacks, and Jews ${ }^{14}$.

Laura's sociopolitical consciousness, however, is still a work in progress as the Devil (in the guise of a gardener) reminds her at their meeting in Folly Wood after she has seen Titus back down to London. While the Devil does not literally rob the rich to give to the poor like Robin Hood, he does demand that his followers adhere to a social ethic that engenders a just society and does not 
favour the few at the expense of the many, something with which Laura still struggles, given her class standing. For instance, Laura is indignant when the Devil implies that Titus and Mr. Jones are souls equal to Laura's for his purposes, and he responds that she is 'not [his] only conquest, and [he is] not a human master to have favourites among [his] servants. All are souls that come to [his] net' (p.130). Yet the Devil's disinterest in the trappings of patriarchal power, particularly its predilection for regime building, which are nothing more than 'card-houses' to him in Laura's estimation (p.124), is one of the reasons that draws her to him.

Jane Marcus maintains that 'the destruction of the patriarchal city and the return of the power of nature' that Laura attributes to the Devil 'represents a fierce feminist commitment to the common urge to wipe out men's cities of oppression and start again' (1984, p.156), and Laura's move to Great Mop and subsequent self-declaration as a witch certainly indicate this, especially in her assertion that one becomes a witch 'to have a life of one's own, not an existence doled out to you by others' (Warner, 1986, p.129). What remains essential, however, is that Laura recognizes that her oppression is just one example of the many forms domination takes, and that she, herself, by virtue of her class standing, could easily become an oppressor if she is not vigilant to her newfound craft.

Although Summer Will Show is considered one of Sylvia Townsend Warner's more political novels, Lolly Willowes can be viewed as a prototype for this text and politically radical in its own right. Along with its feminism, Lolly Willowes conjures a class-free society, one that divines communism through the archetype of witchcraft, and especially through Warner's historical and sociopolitical markers that reference her own emerging politics.

\section{NOTES}

1. See Gillian Beer; Jane Marcus.

2. Laura's musings are reminiscent of the description in Ward, Lock \& Co's illustrated guidebook, London 1914 A 
Pictorial and Descriptive Guide to London and Its Environs: 'The eastern side of London Bridge is nearly always lined by interested spectators, some of whom spend hours in watching the loading and unloading of vessels in the Pool' (p.27).

3. Wachman points out that in at least two articles by Warner, 'Behind the Firing Line: Some Experiences in a Munitions Factory' published in Blackwood's Edinburgh Magazine in 1916 and 'The Way By Which I have Come' (The Countryman XIX, No. 2, July 1939), Warner discusses the sociopolitical implications of her factory experience and its effect on her political consciousness (Wachman p.73).

4. In 1656, Oliver Cromwell's government officially 'readmitted' Jews to England, due partly to the economic benefits of Jewish business with England, and also to some facets of nonconformist ideology espousing that an international 'conversion of the Jews' would bring about the return of Christ.

See http://www.olivercromwell.org/jews.htm.

5. The Bayswater Synagogue was located at Chichester Place, Harrow Road, from 1863 to 1965 , and was at the centre of the Anglo-Jewish community of London's Westside during the Victorian era. The synagogue's principal rabbi, Rev. Dr. Hermann Adler (1839-1911) was elected British Chief Rabbi in 1891. (www.jewishgen.org/jcr-uk/london/bayswater/index.html) 6. Lucas elaborates in a later chapter in The Radical Twenties that the 1920 strike by London dockers was in response the British government's decision to assist Poland in its war against Soviet Russia: 'Dockers refused to load the munitions and prevented the boat intended to carry arms from sailing. In his account of this episode Henry Pelling concludes that while there is no certainty that the dockers' action forced the government to change its mind, there is also no doubt that Lloyd George did stop sending aid to Poland' (p.140).

7. While the novel is meant to show the possibilities for positive social change through cross-cultural collaboration, Warner's depiction of Jews in Summer Will 
Show has been criticized for being stereotypic, even though most of the anti-Semitic commentary is coming through the perspective of an elite, mid-Victorian English character whose views would be consistent for her time and social class. Furthermore, Maren Tova Linett argues in Modernism, Feminism, and Jewishness (2007) that Warner undermines stereotypical views of Jewishness in Summer Will Show.

8. Unfortunately space precludes both a deeper analysis of Anglo-Jewish radical politics when Warner was writing Lolly Willowes and the Jewish significance in both novels. For instance, it would be interesting to consider Warner's Anglo-Jewish references in light of Max Weber's Protestant Work Ethic and the Spirit of Capitalism (1905) and Werner Sombart's The Jews and Modern Capitalism (1911).

9. The problem with alluding to menstruation at this point of Laura's life (she is 47 ) is that she is clearly exhibiting signs of perimenopause, such as poor sleep, hot-flashes, indigestion, and a short temper.

10. British pre-decimal currency which ended in 1971. There were 12 pennies $(12 \mathrm{~d})$ in one shilling $(1 /-)$ - the equivalent of $5 \mathrm{p}$ in the new currency - and there were $20 /-$ in a pound $(£ 1)$.

11. Welsh witch B. H. Cummings contends that Murray's depiction of the Horned God as the god of the witches is inaccurate at best since in certain Wiccan traditions this figure is considered more as a consort to the goddess than as a godhead.

12. Marcus points out that Great Mop is also a 'play on a witch's broomstick' (1984, p.152).

13. One need not be Freud (what Warner was thinking about in the teashop when she overhears the conversation) to understand how the adolescent Sylvia Townsend Warner, in learning that the Tzar and his associates are viewed as 'puppets' within a corrupt and repressive state in 1910, became the woman who joined the Communist Party of Great Britain in the 1930s. Whether Miss Viner existed or not is beside the point - what is significant is that Warner constructs an alleged memory from her 
youth, imbues it with a sentiment that does not side with the Russian establishment (with its links to the British royal family), and ends with the line, 'Nobody wants those old-fashioned transformations nowadays' (Warner 1981, p 100).

14. By invoking the Devil and asking of his help to release her from Titus and her family's control, Laura is mirroring Moses in his efforts to free Jews from their bondage to the Pharaoh. Warner will continue to explore the connection between gender, racial, and Jewish oppression in Summer Will Show.

\section{WORKS CITED}

BEALS, P. Personal Interview. 20 May 2012.

BEER, G. (1999) 'Sylvia Townsend Wamer, "The Centrifugal Kick" in Women Writers of the 1930s: Gender, Politics and History. Ed. Maroula Joannou. Edinburgh: Edinburgh UP, pp. 76-86.

CUMMINGS, B. (2012) Personal communication with the author.

HOROWITZ, I.L. (1986) 'The Jews and Modern Communism: the Sombart Thesis Reconsidered' in Modern Judaism, 6.1., pp. 13-25. http://www.jstor.org/stable/1396501. Accessed 23 May 2012.

KALATA, K. (2005) "There Was a World of Things... and a World of Words": Narration of Self through Object in Sylvia Townsend Warner's Scenes of Childhood.' Tulsa Studies in Women's Literature. 24.2. The Feminist Legacy of Carolyn Heilbrun. pp.319-339. http://www.jstor.org/stable/20455243. Accessed 23 May 2012.

KNOLL, B. (1993) "“An Existence Doled Out": Passive Resistance as a Dead End in Sylvia Townsend Warner's Lolly Willowes.' Twentieth Century Literature. 39.3 pp.344-363. http://www.jstor.org/stable/441691.Accessed 23 May 2012

LUCAS, John. (1999) The Radical Twenties: Writing, Politics, and Culture. New Brunswick: Rutgers UP. 
MARCUS, J. (1984) 'A Wilderness of One's Own: Feminist Fantasy Novels of the Twenties: Rebecca West and Sylvia Townsend Warner' in Women Writers and the City. Ed. Susan Merrill Squier. Knoxville: U of Tennessee P. pp.134-160.

MUIRHEAD, F. (1924) The Blue Guides: England. London: Macmillan.

MURRAY, M. (1962) The Witch-Cult in Western Europe (1921). London: Oxford UP.

\section{Oxford UP.}

(1970) The God of the Witches (1931) New York:

NESBITT, J.P. (2003) 'Footsteps of Red Ink: Body and Landscape in Lolly Willowes' in Twentieth Century Literature. 49.4. pp.449-471.

http://www.jstor.org/stable/3176035. Accessed 23 May 2012.

NO AUTHOR. (1914) London 1914: A Pictorial and Descriptive Guide to London and Its Environs. London: Ward Lock \& Co.

SEAL, G. (2009)'The Robin Hood Principle: Folklore, History, And the Social Bandit' in Journal of Folklore Research 46.1. pp. 67-89.

http://muse.jhu.edu.ezproxy.lib.gla.ac.uk/journals/journal _of_folklore_research/v046/46.1.seal.html. Accessed 23 May 2012.

SHIN, J. (2009) 'Lolly Willowes and the Arts of Dispossession' in Modernism/Modernity. 16.4. pp. 709 725.

http://muse.jhu.edu/journals/mod/summary/v016/16.4.shi n.html Accessed 23 May 2012.

WACHMAN, G. (2001) Lesbian Empire. New Brunswick: Rutgers UP.

WARNER, S.T (1981) 'The Golden Rose' in Scenes of Childhood. New York: Viking. Viking.

(1982) Letters. Ed. William Maxwell. New York:

(1986) Lolly Willowes, or The Loving Huntsman (1926) in Four in Hand: A Quartet of Novels. Introd. William Maxwell. New York: Norton. 